\title{
Proposed Implementation of Life Cycle Assessment (ISO 14040) on Spiced Boneless Milkfish (Chanos chanos) Production
}

\author{
Wahyu Supartono*, Widha Septi Utami, Darmawan Ari Nugroho \\ ${ }^{1}$ Department of Agroindustrial Technology, Faculty of Agricultural Technology \\ Universitas Gadjah Mada, Jl. Flora No.1 Bulaksumur 55281, Indonesia. \\ Email: wstono@ugm.ac.id*
}

\begin{abstract}
Milkfish (Chanos chanos) is one of the main commodities in Kendal District - Middle Java Province - Indonesia. It is produced for spiced boneless milkfish by some smallmedium enterprises. Level of energy usage, emission release, and environmental impacts caused during the production need to be assessed for improvement in these industries. A common method for assessing energy usage and environmental impacts from industrial activity is Life Cycle Assessment (LCA) or ISO 14040. This study used LCA to assess energy, emission and environmental effect of the life cycle of spiced boneless milkfish production. The research was conducted at three small-medium enterprises in Kendal District namely; UKM Ratu Bandeng, UKM Bandeng Kendal, and UKM Rozal Bandeng. The product life cycle started from purchasing raw and supported materials, boneless processing, spiced boneless processing and storage of finished products. Energy measurement was taken place at all energy used during the production, such as human energy, energy from fuel and gasoline and electricity. The released emissions were measured in $\mathrm{CO}_{2}, \mathrm{SO}_{2}$, and $\mathrm{NOx}$. The results depicted that energy needed to produce 1 kilogram of spiced boneless milkfish was 18.456 MJ for UKM Ratu Bandeng; 18.188 MJ UKM Bandeng Kendal and 23.985 MJ for UKM Rozal Bandeng. The emission released was $227.666 \mathrm{~g} \mathrm{CO}_{2} ; 0.333 \mathrm{~g} \mathrm{SO}_{2} ; 2.713 \mathrm{~g} \mathrm{NOx}$ in UKM Ratu Bandeng; $607.459 \mathrm{~g} \mathrm{CO}_{2}$; $0.513 \mathrm{~g} \mathrm{SO}_{2} ; 4.434 \mathrm{~g} \mathrm{NOx}$ in UKM Bandeng Kendal; and 1132,938 $\mathrm{g} \mathrm{CO}_{2} ; 0,941 \mathrm{~g} \mathrm{SO}_{2}$; $8.101 \mathrm{~g} \mathrm{NOx}$ in UKM Rozal Bandeng respectively. Wastewater was produced from the material cleaning process and rest of boiling water, while solids waste were scrap from the materials, such as raw and additive materials, and packaging materials. Recommendations for improvements in these industries were as follow; selection of supplier which was closer to the location of production, use of more efficient production equipment, improvement of production process design, and build tanks and infiltration basin for waste water disposal.
\end{abstract}

Keywords: Emissions, energy, LCA, spiced boneless milkfish.

\section{INTRODUCTION}

Kendal is a district in Middle Java Province and has potency of brackish water, which is suitable for some fish ponds. The district has 3,393.17 ha fish ponds and mostly for milkfish fisheries. Production of milkfish in Kendal district could reach 7,107 tons/year in 2009 (DKP, 2009). This huge production inspired some small medium enterprises to produce new products which were accepted by consumers. Actually fresh milkfishes are still sold in traditional and supermarkets as well. But the consumers did not like these fishes with bones or spiny, so this situation made the producers to create "new product" based on milkfish, namely spiced boneless milkfish.

This product is produced by removing bones or spiny in the fresh milkfish, then it was cooked with some spices before it was packed in vacuum and stored in frozen condition. The fishes were sold in vacuum packed and frozen, so that they have longer shelf-life although no preservative agents added. But in term of energy and waste management, all the producers do not pay any attention. They produced the spiced boneless fishes without any attention on number of energy used, solid, liquid and gas management, and influences on environment as well. Actually when they took into account the energy, emission and other 
wastes, they could optimized their energy needs, raw materials, spices, reduced emission and waste as well. They could also improve their industrial performance and lead to reduce the production cost.

Method for evaluating the industrial system in term of energy usage and emission released is Life Cycle Assessment (LCA) or ISO 14040. In general ISO 14000 series focused on environmental management system and some of which dealt some with providing material, processing, distribution and waste management. ISO 14040 or Life Cycle Assessment is defined as macro scale approach for identifying possibilities to prevent pollution based on individual product and also to trace energy balance, raw material and waste and impact on socio-economic. LCA is also a tool to evaluate the environmental and social performance of products or services along their life cycle (UNEP, 2011).

This research was aimed to identify the energy usage, materials and released waste to the environment for all steps in the production line, and then to give recommendations for optimization of production factors and reduction of waste effect to environment. Some small medium enterprises were chosen as samples at Kendal district.

\section{MATERIAL AND METHODS}

The research was conducted at Kendal district and three SMEs samples were chosen for determining the energy and material usage, the released waste to environment respectively. UKM Ratu Bandeng, UKM Bandeng Kendal and UKM Bandeng Rozal were used as samples for this research. Three SMEs had different specification and production capacity. The reference for calculating the energy usage and other parameters was $1 \mathrm{~kg}$ finished product or spiced boneless milkfish.

The research was started from providing raw materials from ponds or supplier, all materials which were needed for production to finished products. The basic calculation for LCA used energy and mass balances from providing fresh milkfishes to spiced boneless ones. Some steps should be done for determining LCA, emission, and wastes, which were: a) defining goals and scoping LCA; b) Life Cycle Inventory; c) Impact analysis and assessment; d) Interpretation of results and giving recommendations for improvement.
The product life cycle started from purchasing raw and supported materials, boneless processing, spiced boneless processing and storage of finished products. The energy measurement was taken place at all energy used during the production, such as human energy, energy from wood, fuel, gasoline and electricity. The released emissions were measured in $\mathrm{CO} 2, \mathrm{SO} 2$, and $\mathrm{NOx}$ (equivalent).

Primary data which was taken at location, such as how they produced the fishes, how many workers worked and for how long, and secondary data from literatures, emission standard, references on energy and environmental effect analysis were used for calculating, analysis and interpretation of LCA for spiced boneless milkfishes.

Some equations were used such as human consumption energy (Muslimah, 2006) as follow:

$$
\begin{aligned}
& \mathrm{Y}=1.80411-0.0229038 \mathrm{X}+4.71733 .10^{-4} \mathrm{X}^{2} \\
& \mathrm{Y}=\text { energy }(\mathrm{kcal} / \mathrm{min}) \\
& \mathrm{X}=\text { heart beat } / \mathrm{min}
\end{aligned}
$$

For electricity used the equation; $\mathrm{W}=\mathrm{P} \mathrm{x}$ $\mathrm{t}$, whereas $\mathrm{W}=$ electricity energy (joule); $\mathrm{P}=$ power (watt) and $\mathrm{t}=$ time difference (second)

The secondary data such as $1 \mathrm{~kg}$ gasoline produced $72.5 \mathrm{MJ}$; Liquid Petroleum Gas (LPG) contributed 42.27 MJ per $\mathrm{kg}$ and $1 \mathrm{~kg}$ wood of Avicennia sp yielded 22.5 MJ (EPA, 2008).

\section{RESULT AND DISCUSSION}

Spiced boneless milkfish is one of favorite foods in Kendal. It was introduced in 2007 at household scale producer, Ratu Bandeng. This producer up to now played also as supplier of boneless milkfish for other similar producers. The 3 samples had different specification that was presented at Table 1.

The differences among producers showed how they managed their production started from providing type and amount of raw material. UKM Bandeng Kendal used fresh boneless milkfish which was produced by fishermen. It did not conduct process for removing bone form fishes, two other producers conducted this step. It could lead to difference use of energy and less material 
usage based on $1 \mathrm{~kg}$ finished product or product ready to be sold to the market.

Table 1 Producer specification

\begin{tabular}{|l|l|l|l|}
\hline Specification & $\begin{array}{l}\text { UKM } \\
\text { Ratu } \\
\text { Bandeng }\end{array}$ & $\begin{array}{l}\text { UKM } \\
\text { Bandeng } \\
\text { Kendal }\end{array}$ & $\begin{array}{l}\text { UKM } \\
\text { Rozal } \\
\text { Bandeng }\end{array}$ \\
\hline \hline Established in & 2007 & 2005 & 2001 \\
\hline Raw material & $\begin{array}{l}\text { Fresh } \\
\text { milkfish }\end{array}$ & $\begin{array}{l}\text { Fresh } \\
\text { boneless } \\
\text { milkfish }\end{array}$ & $\begin{array}{l}\text { Fresh } \\
\text { milkfish }\end{array}$ \\
\hline Production/day & $100 \mathrm{~kg}$ & $50 \mathrm{~kg}$ & $50 \mathrm{~kg}$ \\
\hline Working hour & $\begin{array}{l}07.00- \\
17.00\end{array}$ & $\begin{array}{l}07.00- \\
14.00\end{array}$ & $\begin{array}{l}11.00- \\
18.00\end{array}$ \\
\hline Labor & $\begin{array}{l}5 \text { persons } \\
\text { persons }\end{array}$ & $\begin{array}{l}5 \\
\text { persons }\end{array}$ \\
\hline
\end{tabular}

Table 2 LCA for $1 \mathrm{~kg}$ spiced boneless milkfish

\begin{tabular}{|l|l|l|l|}
\hline Parameters & $\begin{array}{l}\text { UKM } \\
\text { Ratu } \\
\text { Bandeng }\end{array}$ & $\begin{array}{l}\text { UKM } \\
\text { Bande } \\
\text { ng } \\
\text { Kendal }\end{array}$ & $\begin{array}{l}\text { UKM } \\
\text { Rozal } \\
\text { Bandeng }\end{array}$ \\
\hline Energy & $18.456 \mathrm{MJ}$ & $\begin{array}{l}18.188 \\
\text { MJ }\end{array}$ & $23.985 \mathrm{MJ}$ \\
\hline $\begin{array}{l}\text { Emission of } \\
\text { CO2 }\end{array}$ & $227.666 \mathrm{~g}$ & $\begin{array}{l}607.459 \\
\mathrm{~g}\end{array}$ & $\begin{array}{l}1,132.938 \\
\mathrm{~g}\end{array}$ \\
\hline $\begin{array}{l}\text { Emission of } \\
\text { SO2 }\end{array}$ & $0.333 \mathrm{~g}$ & $0.513 \mathrm{~g}$ & $0.941 \mathrm{~g}$ \\
\hline $\begin{array}{l}\text { Emission of } \\
\text { NOx }\end{array}$ & $2.713 \mathrm{~g}$ & $4.434 \mathrm{~g}$ & $8.101 \mathrm{~g}$ \\
\hline $\begin{array}{l}\text { Scope } \\
\text { maw } \\
\text { market } \\
\text { transporta } \\
\text { tion) }\end{array}$ & $\begin{array}{l}\text { Raw } \\
\text { material } \\
- \\
\text { market } \\
\text { (transpo } \\
\text { rtation) }\end{array}$ & $\begin{array}{l}\text { Raw } \\
\text { material - } \\
\text { market } \\
\text { (transportat } \\
\text { ion) }\end{array}$ \\
\hline Note & $\begin{array}{l}\text { Wood for } \\
\text { processing }\end{array}$ & None & None \\
\hline
\end{tabular}

Other difference was amount of workers of each producer, UKM Ratu Bandeng had more workers than others and it was in line total production per day. The total human energy of UKM Ratu Bandeng was the highest, but probably human energy per kg product was not since the UKM Rozal Bandeng depicted the lowest $(0.067 \mathrm{MJ} / \mathrm{kg}$ product). The result of LCA value for $1 \mathrm{~kg}$ finished spiced boneless milkfish for each producer was depicted in Table 2.

The result indicated that UKM Rozal Bandeng needed more energy for producing spiced boneless milkfish and released more emission to the environment than other producers. UKM Ratu Bandeng still used woods for energy source and developing flavor of fishes. This did not influence on the energy usage and emission released.

Table 3 Energy usage of three UKMs in Kendal for producing $1 \mathrm{~kg}$ spiced boneless milkfish

\begin{tabular}{|l|l|l|l|}
\hline Parameters & $\begin{array}{l}\text { UKM } \\
\text { Ratu } \\
\text { Bandeng }\end{array}$ & $\begin{array}{l}\text { UKM } \\
\text { Bandeng } \\
\text { Kendal }\end{array}$ & $\begin{array}{l}\text { UKM } \\
\text { Rozal } \\
\text { Bandeng }\end{array}$ \\
\hline \hline Energy & $\begin{array}{l}18.456 \\
\text { MJ }\end{array}$ & $\begin{array}{l}18.188 \\
\text { MJ }\end{array}$ & $23.985 \mathrm{MJ}$ \\
\hline Gasoline & $7.963 \mathrm{MJ}$ & $\begin{array}{l}13.058 \\
\text { MJ }\end{array}$ & $16.813 \mathrm{MJ}$ \\
\hline Human & $0.147 \mathrm{MJ}$ & $0.215 \mathrm{MJ}$ & $0.067 \mathrm{MJ}$ \\
\hline Liquid gas & $0.42 \mathrm{MJ}$ & $1.826 \mathrm{MJ}$ & $3.36 \mathrm{MJ}$ \\
\hline Woods & $9.015 \mathrm{MJ}$ & - & - \\
\hline
\end{tabular}

Most energy usage was for transportation, from providing raw material and supporting materials such as spices and packaging materials, and from producer to market for selling the products. They bought most of their need for production at relatively far from the production location and also provided in small amount. It meant, the energy usage was not efficient.

Based on table 3 it was seen that UKM Ratu Bandeng used woods as its heat source. Furthermore woods could establish certain flavor and taste, which were identified as special flavor and taste. Gasoline played important role for this industry, because its percentage was highest among other energy sources namely $43 \%$ for UKM Ratu Bandeng, $70 \%$ for UKM Bandeng Kendal and $71 \%$ for UKM Rozal Bandeng. Most of them used gasoline for transportation. Although the human energy gave small contribution to the energy, it played important role in all processing steps, because the workers made the products in good quality and accepted by consumers.

Effect on the environment was depicted with emission released and based on EPA (2006), that CO2 contributed to global warming, SO2 contributed to acidification or causing acid rain and human health, NOx played important role on acid rain, eutrophication and human health. Gas CO2 gave about $50 \%$ to global warming comparing with other gases such as $\mathrm{CH} 4$ and CFC. Gases of SOx and NOx reacted with water vapor in 
atmosphere and oxidation occurred. The yield of the oxidation was such as strong acids $\mathrm{H} 2 \mathrm{SO} 4$ and HNO3, which were influenced the rain water become more acid.

\section{CONCLUSION}

Conclusions of the manuscript should state clearly its implications for our understanding of the science and technology. Based on the research results, some points could be concluded as follow:

1. Energy usage for producing spiced boneless milkfish was human energy, electricity, energy from gasoline and fuels, and woods. For producing $1 \mathrm{~kg}$ product it was needed 18.546 MJ UKM Ratu Bandeng, 18.188 MJ UKM Bandeng Kendal and 23.985 MJ UKM Rozal Bandeng.

2. The emission released was $227.666 \mathrm{~g}$ CO2; 0.333 g SO2; 2.713 g NOx in UKM Ratu Bandeng; 607.459 g CO2; 0.513 g SO2; $4.434 \mathrm{~g}$ NOx in UKM Bandeng Kendal; and 1132,938 g CO2; 0,941 g SO2; 8.101 g NOx in UKM Rozal Bandeng respectively.

3. Liquid waste was produced from the material cleaning process and rest of boiling water, while solids waste were scrap from the materials, such as raw and additive materials, and packaging materials.

4. Some recommendations for optimizing the material and energy usage and reducing environmental impacts were; to choose the supplier near the location of producers, to use the equipment which was efficient in energy use, to improve production process design and to build tanks and filtration basin for waste water disposal.

\section{REFERENCES}

United Nation Environment Program (UNEP). 2011. Global Guidance Principles for Life Cycle Assessment Database.

Environmental Protection Agency (EPA). 2006. Life Cycle Assessment: Principle and Practice. EPA. Ohio.

Environmental Protection Agency (EPA). 2008. Compilation of Air Pollutant Emission Factors. EPA. Ohio.
Dinas Kelautan dan Perikanan (DKP) Kabupaten Kendal. 2009. Potensi Perikanan dan Kelautan - Komoditas Unggulan Bandeng. In www.kendalkab.go.id. Accessed on 14th April 2012.

Muslimah, E; I. Pratiwi and R. Rafsanjani. 2006. Analysis on Manual Material Handling using NIOSH EQUATION. Jurnal Ilmiah Teknik Industri Vol. 5 No. 2 Desember 2006. Universitas Muhammadiyah Surakarta. Surakarta. pp: 53-60 